\title{
Paideusis
}

\section{Educational Policy for a Pluralist Democracy: The Common School, Choice and Diversity (Mark Holmes)}

\section{Geoffrey Partington}

Volume 8, Number 1, 1994

URI: https://id.erudit.org/iderudit/1073264ar

DOI: https://doi.org/10.7202/1073264ar

See table of contents

Publisher(s)

Canadian Philosophy of Education Society

ISSN

0838-4517 (print)

1916-0348 (digital)

Explore this journal

Cite this review

Partington, G. (1994). Review of [Educational Policy for a Pluralist Democracy: The Common School, Choice and Diversity (Mark Holmes)]. Paideusis, 8(1),

39-43. https://doi.org/10.7202/1073264ar viewed online.

https://apropos.erudit.org/en/users/policy-on-use/ 


\section{Book Review}

\section{Mark Holmes, Educational Policy for the Pluralist Democracy: The Common School, Choice and Diversity (London: Falmer Press, 1992).}

Holmes argues that, in conditions of increased cultural diversity, "low doctrine" or "highest common factor" common schools in western democracies such as the U.S.A., England, Australia, and Canada are losing, or have already lost, the capacity to inspire, or significantly influence, their students and are doomed to impotence. On the other hand, governmental attempts in the name of various modes of political correctness to enforce any particular educational doctrine creates justified resentment among those on whom it is imposed. In any case, despite misleading rhetoric, none of these countries has a common comprehensive school system. Many other schools exist, although permitted exclusions and availability of public financial support seem highly arbitrary: there is public funding in England for Anglican and Roman Catholic but not Muslim schools; in Ontario, for Roman Catholic and Chinese language schools but not Protestant ones; and in Massachusetts, for numerous alternative schools but not for the religious-based schools attended by huge numbers of Roman Catholics and other Christians. In Australia, many vociferous enemies of other forms of government support for non-government schools are enthusiastic advocates of fully-funded schools for Aborigines based on traditional "Dreamtime" beliefs.

Massive population shifts have, of course, greatly increased cultural diversity in many western countries. Even without substantial immigration, greater educational opportunity itself leads to greater occupational mobility, more associative marriages and, thus, to wider intellectual and cultural differences. Most fundamentally, all modern open societies contain several contendingindeed, basically incompatible - sets of educational beliefs which may be held without any obvious affront to reason. Given the fundamental contestability of educational theories and priorities, there seems no justification for advocates of any one position to be able to impose their will on others, although this is what contemporary apostles of political correctness desire.

Holmes identifies six basically different philosophies of education:

1. Child at the centre ("progressive")

2. Success in future life ("technocratic")

3. Intellectual and cultural development ("cultural")

4. Development of good character and personal responsibility ("traditional')
5. Development of individual freedom ("'individualist")
6. Search for social equality ("egalitarian")

This taxonomy is flawed, since it fails to distinguish transcendentalist aims from others, even though Holmes well understands the critical importance to education of religious doctrines. Furthermore, individual success in future life is but one of several types of instrumentalist aim, others being national prosperity and economic efficiency (and vide Durkheim, whom Holmes cites on other counts, social solidarity) which are best grouped together. On the other hand, Holmes' 1 and 5 seem to be two aspects of child-centred approaches to education. Equality or equity is but one of several related reconstructionist aims and is 
commonly purchased in any one dimension at the expense of greater inequality in another. Holmes' main points-that each of these priorities has defensible variants and no good educational grounds exist for excluding any school from public funding simply because it adheres to one or another of them-are entirely sound, however. In place of all-purpose "low-doctrine," common schools, Holmes argues for a series of "high-doctrine" schools both inside and outside the government system and that these should be widely availabe to parents and students. He is himself a passionate advocate of what he terms the "cultural" path, known in the past as "liberal education" before "liberal" came to have very different connotations in North American thought, but he does not seek to impose his priorities on those he hopes to persuade, just as he is unwilling to be coerced by others.

Holmes understands that, for theoretical coherence as well as effective application, any educational policy must provide publicly accessible ways of ascertaining whether or not its aims are being achieved. Nothing is more ridiculous than to proclaim lofty aims, whether relating to literacy, numeracy, self-esteem, moral character, employability, or any other desired end, and then to deny that there is any reliable way of determining whether they are actually being achieved. Holmes discovered that in Ontario "progressives"-especi ally those entrenched in the higher ranks of educational administration-were much more hostile than any other identifiable group to assessing educational achievement, even in order to ascertain whether their own educational aims were being achieved. schooling:

Holmes identifies four sets of policies for the provision of publicly funded

1. The common school (with or without private options)

2. Public diversity (with or without private options)

3. A mix of funding for public and private options

4. A voucher system

He opposes the confinement of full public funding to common schools and argues that, since significant differences of curriculum or pedagogy are often permitted inside them, there is no logic in banning inter-school choice. He attacks public monopolies and draws attention to the inequity of permitting alternatives to the rich whilst denying them to the poor. When examining the possible scope of public diversity through decentralization, school autonomy, and local choice, he notes that many governments, such as that of Ontario, which claim to give wide powers of discretion to individual schools, actually retain extensive central control and require uniformity on the main contestable educational issues of our time. Wider local autonomy and open enrolment which offers choice between "magnet" schools of genuinely distinctive characters may be steps in the right direction, but the replacement of one large central bureaucracy by many local ones may not significantly reduce objections by minorities to educational policies they detest. Injustice might be as great if the tyranny was that of the parish pump and educational uniformity imposed by parental majorities rather than by politicians or bureaucrats. The facts of cultural diversity make it very unlikely that there will be anything like identity between defined geographical "communities" and "communities" formed by persons who share common cultural or educational purposes. It is rare in successful non-government schools that parents play a direct role in making educa- 
tional policy. What parents want is choice and reliable information on which to base choice, not the opportunity to run schools themselves.

Holmes notes that in the United States religious schools teach basic secular skills better than secular schools and more successfully inculcate moral standards in areas of conduct about which wide consensus exists between secularists and religious believers. Parental belief that this is also the case in Australia has been influential in a significant movement away from government schools since the late 1970s. Another factor in this process has been the conviction of many Protestant parents that the state schools in which they once had confidence are no longer merely neutral but hostile towards their values, a tendency found, too, by Holmes in North America. Holmes considers it is wrong to teach children religion against their parents' wishes but extends his disapproval to teaching irreligion against parental wishes. His caveat against "complete faith in reason" seems unreasonable, since it is on the basis of argument and reason that he urges that belief should be invested in certain traditions, virtues, and modes of faith, but he is right to point out that dangers of indoctrination are little different in religious schools from many based on non-religious world views. Indeed, at present in western schools, it is often easier to indoctrinate and proselytise into neo-Marxist beliefs than into Christianity. Ironically, many western Marxists protest that their own teaching is non-ideological almost immediately after they have finished expounding the doctrine that non-ideological texts or pedagogies are impossible. Holmes also shows that problems concerning the relationship between freedom of school texts from censorship and protection of individuals and groups from insult and outrage are little different conceptually in secular and religious schools, despite massive contrasts in what is to be banned and what prescribed. Some ardent secularists advocate sex education in which sodomy and lesbianism are presented as alternative and equally acceptable types of sexual relationship but are outraged by the use of "sexist" pronouns. Many religious believers react in just the opposite directions.

In an extensive treatment of policy alternatives for cultural differentiation or homogenisation, Holmes angues that the more multicultural a society is the less is assimilation feasible, but he might have added that the more it may then become desirable for mainstream opinion. If, for example, groups who practise massive sexual discrimination, perhaps including female circumcision, enter contemporary western societies, the majority is usually very concerned to use schools to change such practices and assimilate the newcomers into western mores as soon as possible. He argues that the failure of the Soviet Union to assimilate its minorities over seventy years, despite using all the powers of full-blooded totalitarianism, suggests western societies have even less chance of effecting assimilation or integration, but Aesop's fable of the sun and the wind may be relevant here. Holmes very ably exposes attempts by counter-culturalist progressive educational establishments in Canada to placate ethnic minorities by abolishing as much of mainstream culture as possible from the curriculum, including the celebration of Christmas and any account of the development from British models of the main national institutions.

Holmes' recommendation is that the state should accept the fact that several different cultures co-exist within it "neither as a problem to be deplored nor as an emblem of signal national virtue" and accept "as a starting point for 
its public schools a set of values and beliefs drawn from its majoritarian culture, but modified by and integrated with other cultural influences from significant minorities." Those who wish to have a different education, based perhaps on one of the minority cultures, would be entitled to set up their own schools with public support but "not necessarily equal financial support," provided that nothing against public law was advocated therein. Holmes believes that the eight principles on which he bases this "pluralist majoritarian" position would provide an adequate framework for a "high doctrine" school. Yet, many of his eight principles are so contestable in interpretation that the situation would be little different from that at present, other than that non-government schools would be funded more generously. Just what is entailed by "the fundamental equality of all citizens," "freedom of speech," "the institutions of family and community," and "equal opportunity," or what are appropriate educational goals in the "moral, academic, vocational, physiological, aesthetic, spiritual, and social domains" are matters about which centrally important educational contests are fought.

Holmes is right in his basic argument that the catch-all common school has little educational meaning or potency, especially as cultural diversity increases. It is in the same position as a coalition government of parties from the far left to the far right which can only act when consensus has been achieved. He recognises that partial government financial support of non-government schools, in so far as it attracts children away from fully-funded government schools, reduces burdens of taxation. Movement to "higher doctrine" nongovernment schools also increases overall parental and student commitment to schools and helps to improve educational standards. Full funding would further this improvement, although it would not, of course, reduce educational expenditure.

Some who object to choice in education claim it leads to greater social inequalities than does the imposition of uniformity. During the nineteenth century, the radical objection was commonly that non-government institutions of the "dame school" type gave an inferior education, but contemporary radicals more typically claim that non-government schools are generally better and so give an unfair advantage to those who attend them. Some even hold that any further weakening of the quasi-monopolies held by government schools would make them utterly unviable. This view is often, of course, combined with incompatible claims that only snobs and reactionaries hold non-government schools to be better and that, all background factors allowed for, government schools are just as good. In any case, in all contemporary western societies, disparities in educational achievement between government schools in the most and the least affluent areas are considerably greater than the mean difference between government and non-government schools.

Holmes is reluctant to accept the logic of his own arguments, which lead inexorably to the desirability of maximising educational choice through voucher systems. He expresses the fear that some parents might "shop around for schools as they might for grocery stores, changing their choice every few months" and that this is unfair since "education and the school deserve some commitment." Yet, very few parents for whom choice is currently available make such frequent changes; even if they did so, it is hard to see that they should be prevented. Many opponents of vouchers use the opposite argument: 
that most parents are so apathetic about their children's education that they would not take advantage of choice.

Holmes rejects as inequitable open-ended voucher systems with no cap on additional fees which may be charged, yet the very rich are not limited by such caps at present and many not-so-rich families pay a lot of extra money for musical, sporting, holiday, and many other experiences for their children which other parents do not and often cannot afford. Is it really inequitable to provide your own children with something better than the least conscientious or the most financially disadvantaged parents can afford? Holmes is also strongly opposed to restrictions on admission to schools, yet it seems absurd that there should be open access of, say, atheist children to religious schools, boys to girls' schools, or-a relevant Australian example-non-Aborigines to schools set up to provide a pervasive atmosphere of Aboriginal traditional culture. To be sure, not many "outsiders" want their children to attend schools defined so as to exclude them, but even to concede a universal right of admission must undermine the very foundations of such schools.

Reviewed by Geoffrey Partington, Flinders University of South Australia

\section{William Hare and John Portelli. What To Do? Case Studies For Teachers (Halifax, N.S, Fairmount Books, 1993).}

\section{William Hare, What Makes A Good Teacher (London, Ontario: Althouse Press, 1993).}

The purpose of What to Do? by Hare and Portelli is to describe how they try to engage their education students in "doing" philosophy as it relates to teaching. In the first half of the book, they explain and argue for the use of educational case studies to advance student teachers' thinking about teaching. Hare and Portelli see this as a useful extension to what they say are the usual methods of teaching undergraduate philosophy. These methods they outline as, presenting the different 'isms' (such as progressivism) and the educational prescriptions that seem to follow from these; introducing analytic philosophy and examining important educational concepts; and a combination of these two with, in addition, the introduction of different educational ideologies. Philosophy should be more than a set of artifacts, the authors assert; it should relate to the way we live our lives. Certainly beginning teachers are in need of thoughtful guidance as they struggle to learn techniques and methods and the norms of the school while remaining aligned with their own values.

Using cases to explore ways of understanding and dealing with common problems of practice is an approach long used in medicine and law, and rather recently adopted in education. One way of using cases, as Lee Shulman has done, is to see the presentation of problematic stories of practice as a way of communicating knowledge about teaching. Hare and Portelli feel that the presentation of cases as illustrations of expert knowledge of teaching may be misleading, because problems of practice do not have clearcut answers. As well, such presentation does not encourage students to be critical and to raise the important value questions that well written cases can invoke. Hare and Portelli 